\title{
Study of potential fish resources in senayang waters, Lingga district
}

\begin{abstract}
One of the problems in the conservation of demersal fish in Senayang waters is that there are still many trawlers, which used the small mesh-sized net that will negatively impact the sustainability of fish resources. This study aims to determine the potential sustainability of fish resources by using the analysis of the catches of fishermen landed at TPI Senayang and information from fishing gear in the area. The study used a survey method through trawlers observation by interviewing trawlers, then analyzed descriptively. The continuous potential was calculated using the Schaeffer method. The trawlers used mesh sizes of 1.5 inches on average. Schaeffer's analysis shows that the total production of catches of 854.07tons by operating trawlers as much as 831 times this operation alone actually does not support the potential of sustainable and unsustainable fish resources. Based on the results of an analysis of the number of fishing operations and the total production of fish caught shows that there are many seine fishing operations, it is not accompanied by an increase in the total amount of catch production. The average level of potential utilization of Senayang waters has reached $80.47 \%$, which means that the use of trawlers in Senayang waters no longer supports the conservation of demersal fish. In the management of demersal fish fisheries in Senayang waters, the government must regulate the size of fish that can be caught, namely by limiting the size of the net mesh on trawlers, and in its operation, there must be strict supervision so that this rule is implemented consistently. Besides, to prevent the level of utilization that can interfere with the preservation of fish stocks in the Senayang waters, zoning needs to be made and regulated to set a sustainable catch quota.
\end{abstract}

Keywords: trawler, catch, sustainable potential, Schaeffer method
Volume 5 Issue I - 2020

\author{
Kamaruddin Eddiwan \\ Faculty of Fisheries and Marine Science, Riau University, \\ Pekanbaru, Riau, Indonesia \\ Correspondence: Kamaruddin Eddiwan, Faculty of Fisheries, \\ and Marine Science, Riau University, Campus Bina Widya Km \\ 12,5,Pekanbaru, Riau, Indonesia 28293, \\ Email eddiwa@lecturer.unri.ac.id
}

Received: January 08, 2020 | Published: February 07, 2020

\section{Introduction}

Demersal fish have high economic value because of its distinctive taste and are favored by consumers. ${ }^{1}$ Low growth speed and relatively small potential but the high economic value and demersal fisheries must be managed properly. ${ }^{2}$ Capture fisheries production in Lingga Regency is mostly dominated by demersal fish as much as $63.7 \%$ of the total capture fisheries production reached 854.4tons in 2017. One of the problems in conserving demersal fish in Senayang waters is demersal fishing using trawl fishing gear, with a small mesh size, it is suspected that there are still many fishermen using trawl fishing gear, and this will certainly affect the recruitment of demersal fish in Senayang waters.

Production obtained from demersal fishing gear in Senayang based on 2017 data contributed 428,481 tons or $35.87 \%$ of total demersal fish production. The production of marine fisheries in Senayang from 2018 to 2019 is unstable and even tends to decrease. ${ }^{3}$ This decline in a catch can be used as an indicator of fishing that exceeds the potential for sustainability. ${ }^{4}$ Such conditions need to be managed well through adjusting business arrangements with the carrying capacity of fish resources. Knowledge about fish populations is the most basic thing from an analysis of fish resource stocks. This is very important in planning in the management of fisheries resources. Therefore, the need for the management of demersal fish resource potential in Senayang waters can be used sustainably. According to ${ }^{5}$ fisheries resource management requires data on the maximum potential of sustainable fish resources as material for the regulation and development of fisheries in the area. The development and utilization of fisheries resources cannot be stimulated without paying attention and seeing the limits of the ability of resources to produce, because fisheries resources have limits on the carrying capacity of the environment (sustainable potential), even though they have the power to restore. This study aims to examine information about the sustainable potential of the demersal trawl fishing business through the analysis of the catch landed at TPI Senayang and information on trawl fishing gear.

\section{Methodology}

\section{Time and place}

This study was conducted in June 2019 at TPI Senayang which is one of the places in Indonesia, where fishermen get their catch, which is harvested by trawl fishing.

\section{Research methods}

This research was conducted by survey method. The observation technique of fishing gear is done by interviewing the fishermen who use trawlers who operate in Senayang waters, whose catch is landed at TPI Senayang, Lingga Regency. Lingga residents, both as boat owners, skippers and crew using fishing trawlers were used as respondents in this study. The total number of respondents amounted to 168 people from a population of 741 . The purpose of the interview with respondents was to find out information about the production of trawlers, and the operational fishing ground of trawlers in Senayang waters. 
Primary data include types of fishing trawlers, how they operate fish trawlers. While secondary data used are fisheries data from 2008 to 2017 concerning the number of demersal fish production caught with trawl fish, obtained from relevant agencies such as the Lingga Regency Fisheries Service, TPI Senayang, and Lingga Regency BPS and various libraries related to this study. Secondary data used to calculate the sustainable potential of demersal fish resources captured by trawlers.

\section{Data analysis}

Data analysis conducted with the descriptive-analytic method is the result of observations, interviews, documentation and supporting data. Primary data were analyzed descriptively. The sustainable potential of demersal fish resources using fish trawlers is analyzed using the Schaefer method as follows:

A. The fishing effort per catch unit or CPUE (catch attempt per unit) is estimated using the following formula ${ }^{6}$ :

$$
C P U E i=C i / E i
$$

\section{Where,}

CPUE, catches per capture attempt in the year i (tons/effort); $\mathrm{Ci}$, catch in the i-year (ton); Ei, catching attempt in the i-year (effort); i, year $1,2, \ldots, \mathrm{n}$.

B. The relationship between CPUE and capture attempts was analyzed using the following formula ${ }^{7}$ :

$$
C P U E=a-b f
$$

Regression analysis was performed to get an idea of the effect of capture effort $(f)$ on catch per unit effort (CPUE). Values $a$ and $b$ were obtained from the regression analysis. The simple linear regression equation was intended to determine the magnitude of influence between variables, and also to find out or predict the value of one or more variables.

Maximum sustainable yield (MSY), which is the maximum number of catches allowed so that the availability of capture fisheries resources remains sustainable (sustainable potential), was calculated by using the following formula ${ }^{7}$ :

$$
M S Y=-a 2 / 4 b
$$

Determination of the sustainability status of demersal fish resources by calculating the level of utilization using the following formula ${ }^{8}$.

$$
\text { Utilization rate }=(\text { production } / \text { MSY }) \times 100 \%
$$

\section{Results and discussion}

\section{Trawler}

Size criteria for fishing trawlers which are operated in Lingga Regency waters are those which have a trawl length of $10-12 \mathrm{~m}$, a width of $3-4 \mathrm{~m}$ and a depth of $0.5-1.5 \mathrm{~m}$, with an engine strength of $80-100 \mathrm{PK}$ and a capacity of 5-10GT. This is in accordance with the Minister of Maritime Affairs and Fisheries Regulation No. 2 of 2011, which states that the vessels used to operate fishing trawlers must be under $30 \mathrm{GT} .^{10}$

Trawling fishing gear is a bag-shaped fishing gear made of nets with 2 (two) panels and not equipped with net mouth openings. ${ }^{11}$ The form of fishing gear construction does not have a top net, short wings, and long drawstring. The net length from the end of the bag to the toes/wings is around $8-12 \mathrm{~m}$; the length of the rope is between 100 $200 \mathrm{~m}$. The average size of trawl nets used is 1.5 inches, which is not in accordance with the Minister of Maritime Affairs and Fisheries Regulation No. 02 of $2011^{9}$ that permitted net trawler nets are more than 2 inches. It is feared that the operation of the small mesh size will affect the exploitation of fish resources due to the capture of young fish groups, which still have the potential to grow and lay eggs or breed in nature.

Fishing lanes for fishing trawlers are in capture lanes II (4-12miles) and lane III ( $>12$ miles). ${ }^{9}$ This fishing trawler from Senayang can travel 5-12miles from the coastline, with an operational length of one day. Typically, the fishing area is determined based on natural signs such as the appearance of foam on the surface of the water or the presence of birds that are reaching, but most fishermen use the method by trying to lower the net in the area that is commonly used as a fishing ground for fishermen. Determination of the capture area with trawl gear is almost the same as the basic trawl, where the basic requirements for the basic trawl are as follows:

1. Because the trawl fishing gear is operated by being pulled, the location of the fishing ground must have a seabed consisting of sand or mud, no rock, no objects that might make the trawl tool catch when the trawl net is pulled.

2. Having a flat bottom, there is no significant difference in depth.

3. The waters must have large productivity and abundant water resources. ${ }^{12}$

Some of the criteria above are very suitable for the condition of Senayang waters which have many river mouths. Thus contributing to the supply of suspended sediments and solids as well as providing nutritional inputs that produce abundant fish resources. The waters of Senayang generally consist of sand and mud. ${ }^{13}$

Fishing gear operations are carried out by turning fish hordes in the water base. Then the trawler is pulled by a stopping ship (anchored but with a live engine condition) and is not pulled, because the trawler uses a fishing machine from the ship. ${ }^{14}$ Fishing uses a boat that is in an engine running condition, then the ship will not move backward but the ship will move forward. This is intended not for sweeping swarms of fish at the bottom of the waters, but to accelerate the capture of target fish so that they can immediately enter the net bag. ${ }^{15}$ The area of fishermen's trawl mouth is limited, the level of stirring and water friction is relatively small. ${ }^{16}$ Trawl fishing gear cannot continue fishing operations if the trawler is caught with large and strong objects that are at the bottom of the waters, such as rocks, corals, or iron stakes from iron vessels sinking at the bottom of the water. ${ }^{17}$ With operational methods that are sweeping the bottom of the waters is what causes fishing trawlers called destructive ecosystems at the bottom of the waters. Wherein it is known that ecosystems in the bottom waters are generally spawning grounds for some basic fish species. ${ }^{18}$ In general, one unit of the trawler is operated as many as 6 times or 6-7 times a week is used. ${ }^{19}$

\section{Sustainable potential}

Demersal trawl gears used for fishing in Senayang waters includes mackerel (Rastelliger spp.), layur (Trichiurus lepturus), anchovies (Stolephorus sp.), tigawaja (Tenualosa macrura Bleeker, 1852), petek (Equulites elongatus), and types of shrimp (Crustaceans) as well as squid (Cephalopoda). The volume of production was fluctuated from 2018 to 2017. The results of the production and CPUE of demersal fisheries that obtained from trawlers, presented in Table 1. 
Table I Production volume, capture effort and CPUE of demersal fisheries obtained from trawlers

\begin{tabular}{llll}
\hline Years & Production $\mathbf{( k g )}$ & $\begin{array}{l}\text { Effort } \\
\text { (trawler fishing gear) }\end{array}$ & CPUE \\
\hline 2008 & 735.267 & 824 & 892 \\
2009 & 432.065 & 1.515 & 285 \\
2010 & 804.191 & 1.024 & 785 \\
2011 & 1.036 .537 & 891 & 1.163 \\
2017 & 428.481 & 1.097 & 391 \\
\hline
\end{tabular}

The value of CPUE represents the level of productivity of the effort to capture (effort). The higher CPUE value indicates that the level of productivity of the fishing gear used is also higher. The table shows that production is not stable. When compared with catching attempts, an increase in catching efforts actually decreases the catches. This shows that not always adding fishing gear will increase production as shown below.

From Figure 1, it can be observed that an increase in trawler catches occurs to a certain point when the fishing effort is in position 891 , and if these efforts continue to be increased, then the catch turns out to still not rise or even tend to decrease. In the trial of the unit trawl catching tool, the decline in trawl catches was found when the catching effort continued to be increased. This is alleged because the fishing effort that has been carried out has exceeded the maximum capacity of the fish resources in the waters to be able to restore its condition. The performance of trawlers and their catch production can be calculated by combining several factors in several stock indicators, such as

(i) A decrease in CPUE

(ii) A decrease in the total landed catch

(iii) A decrease in average weight of fish; and ecosystem indicators, namely

(iv) Changes in age structure/size structure or

(v) Changes in species composition in populations. ${ }^{20}$

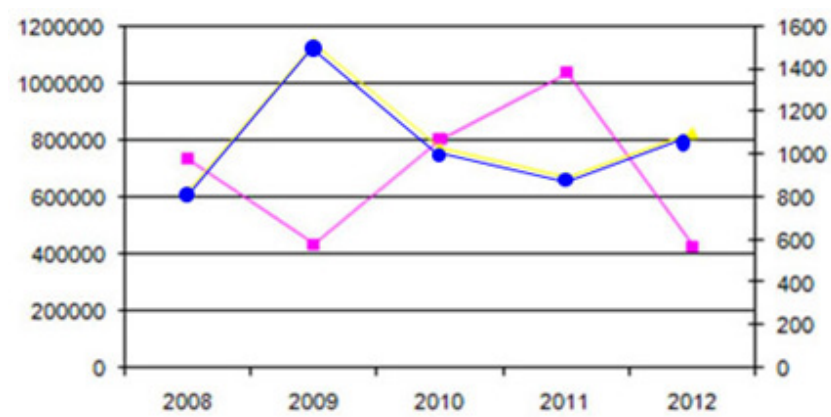

Figure I Relationship between effort and catch.

From the Figure 1 above, explaining that the increase in fishing operations carried out, it turns out to correlate to the decreasing fishing effort per unit. In this case, it can be seen from the catch data that there was an increase in catches from 2008 to 2009 and after that; there was a decline in catch production in the following year. This shows that the difference in the results of fishing effort per unit (CPUE) that has been experiencing a decline. From this data, it appears that the worst CPUE decline occurred when the fishing effort was at its peak in 2009. So, this has given a signal that the more operational efforts of fishing with trawlers, the more according to the production of fish catch per unit. According to Badrudin and Karyana, ${ }^{21}$ the increasing trend of CPUE is a picture that the level of exploitation of fish resources can be said to be still under development. The occurrence of a horizontal CPUE trend, essentially describing the level of exploitation of fish resources in these waters is nearing saturation. While the CPUE trend line that is declining on the graph shows an indication that the level of exploitation of fish resources in these waters has been neglected, and there is a proper control effort. This will lead to a condition called 'more capture' or even 'uncontrolled arrest'.

With fluctuations in CPUE values obtained, it is considered necessary to know the relationship between CPUE values and the fishing effort carried out in these waters. From the results of the regression calculation, the relationship between CPUE and operational capture effort shows a negative relationship. Where the increasing operational business of fishing with trawlers, the CPUE value decreases. The negative correlation between CPUE and fishing effort indicates that the productivity of trawlers for demersal fish will decrease if the trawler fishing operations continue to increase. The relationship between capture effort with CPUE is obtained to be CPUE $=2054.66-1.24 \mathrm{f}$. From these equations, it is known that each additional effort from one trawler unit will reduce CPUE by $2,054 \mathrm{~kg}$ (Figure 2) (Figure 3).

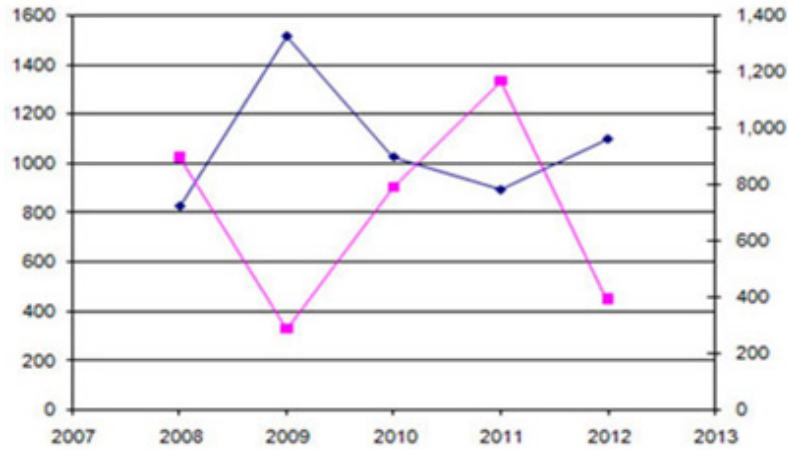

Figure 2 The relationship between capture effort (effort) and CPUE.

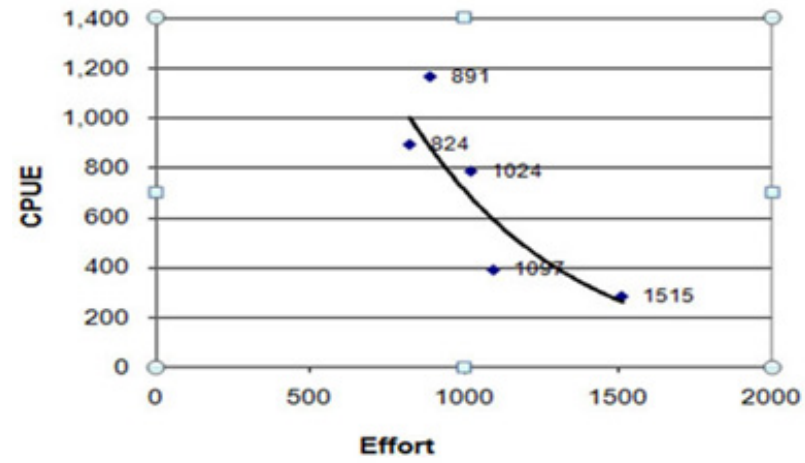

Figure 3 The correlation between capture effort (effort) and CPUE.

The optimum effort is a catching effort that can be done by a fishing gear unit to get the optimal catch without damaging the sustainability of the fish resources. MSY or maximum sustainable catch is the 
highest number of fish stocks that can be caught continuously from an existing potential without affecting the sustainability of the fish stock. By knowing the value of MSY, the level of utilization of a fish resource is expected not to exceed its MSY value so that the sustainability of the resource can be maintained. In other words, the optimal number of catches needs to be known so that any fishing effort does not harm the sustainability of the resource. The benefits of estimating the optimum level of fishing effort are that the loss of time, labor and operating costs of fishing can be minimized and the fishing effort carried out is expected to always achieve optimal results. For optimum fishing efforts, it is necessary to allocate the number of fishing units according to the fishing area and fishing season.

Based on equation $\mathrm{c}=2054.66-1.24 \mathrm{f}$, the optimum effort value can be obtained, which is the optimum level of effort to catch demersal fish, amounting to 831 units of trawlers per year as presented also in Figure 4. MSY value obtained was 854.07 tons which is a boundary where demersal fish resources can still be used without disturbing their sustainability to breed and protect their offspring. The relationship between MSY demersal trawler fishing gear with an effort at the level of maximum sustainable potential (eMSY) and actual conditions (production and effort) for 5 (five) years is presented in Figure 4.

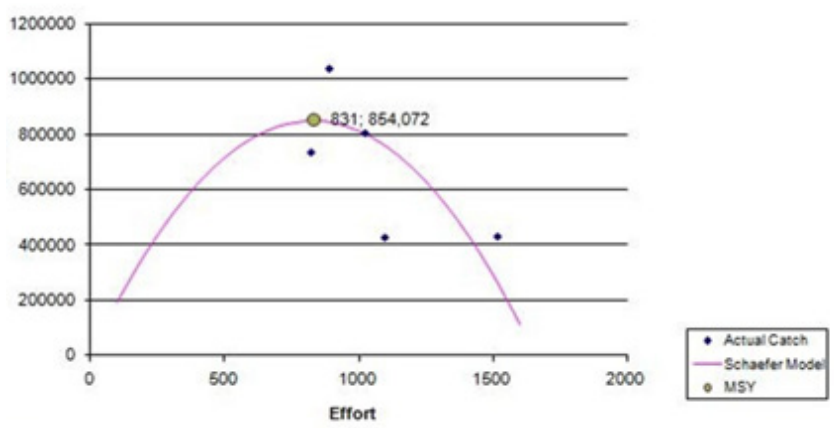

Figure 4 Relationship between MSY, eMSY and the actual condition of demersal fishing trawlers.

By knowing the optimum fishing effort value and the MSY value, the level of utilization of trawler fishing gear demersal fisheries can be known. The average utilization rate from 2008 to 2017 obtained a value of $80.47 \%$. This means that fishing efforts have exceeded the sustainable potential that should be allowed to be caught, which according to Muhammad ${ }^{8}$ revealed that the use of fishery resources above $80 \%$ does not support the sustainability of these resources. Indications of overfishing include the increase in catches continuously from year to year until the year after which there is a very drastic decrease in catches, even though the fishing effort is increased.

\section{Conclusion}

Trawler fishermen in Senayang used a mesh size of 1.5 inches that is not in accordance with the regulations. The results of Schaeffer's analysis showed that the sustainable potential is 854.07 tons with a catch effort of 831 units of trawlers. Based on the results of the analysis, it is known that the high level of fishing gear effort is not accompanied by high production. The utilization of demersal fishing trawlers in Senayang waters has exceeded their conservation potential with a utilization rate of $80.47 \%$, which means that the use of trawlers does not support the preservation of demersal fish. Thus, the waters of Senayang have experienced overfishing. The potential of demersal fish resources in Senayang waters was decreased due to the lack of control of fishing as indicated by the high level of utilization. This caused the demersal fish resources still not to be fully developed and also to be caught by the fishermen without getting the chance to renew themselves. Therefore, it could be recommended that the government must have to impose regulations on limiting the size of fish that can be caught by limiting the size of the fishing gear net. In addition, to prevent the level of utilization that disrupts the sustainability of the stock, zoning and catch quota arrangements need to be done.

\section{Acknowledgments}

None.

\section{Funding}

None.

\section{Conflicts of interest}

Authors declare no conflict of interest exists.

\section{References}

1. Wilhelmsson D, Malm T, Öhman MC. The influence of offshore windpower on demersal fish. ICES Journal of Marine Science. 2006;63(5):775-784.

2. Bianchi G, Gislason H, Graham K, et al. Impact of fishing on size composition and diversity of demersal fish communities. ICES Journal of Marine Science. 2000;57(3):558-571.

3. Lingga regency fisheries and maritime service strategic plan 2017-2016. Department of maritime affairs and fisheries, Lingga Regency, DKP Kabupaten Lingga; 2017.

4. Widodo J Suadi. Management of marine fisheries resources. Yogyakarta: Gajah Mada University Press; 2006. 252 p.

5. Dwiponggo A, Badrudin M, Nugroho D, et al. Potential and dispersal of demersal fish resources in potential and distribution of marine fish resources in indonesian waters. Director-general of fisheries. Fisheries research and development center and oceanology development research center. Jakarta in Juriono, 2000. 1989.

6. Gulland JA. Fish stock assessment. Rome: Food and Agriculture Organization of the United Nations (FAO) in Astuti, Evie Maulina. 2005. Dimensions of shrimp trawl catching unit and shrimp resource utilization level in Arafura Sea waters. Thesis. Bogor: IPB; 1991

7. Sparre P, Venema SC. Introduction to tropical fish stock assessment. Part 1: Manual, FAO. Research-based fish population dynamics. Undip, Semarang; 1992.

8. Muhammad S. Fisheries household economic studies. Analysis of policy simulation on sustainable fisheries resource management. Dissertation. Postgraduate program, Bogor agricultural university. Development of white snapper fisheries (Lates Calcarifer) in the Mimika Regency. Bogor: IPB; 2002.

9. Ministry of maritime affairs and fisheries. Regulation of the minister of maritime affairs and fisheries number 02 of 2011 concerning fishing tracks and placement of fishing equipment and fishing aids in the territory of the republic of indonesia fisheries management. Marine and Jakarta: Fisheries ministry; 2011.

10. Firdaus M. Fishing catch and catch rate assesment of mini trawl, trapnet and setnet fisheries. 2010;14(1) 
11. Leathwick JR, Elith J, Francis MP, et al. Variation in demersal fish species richness in the oceans surrounding New Zealand: An analysis using boosted regression trees. Marine Ecology Progress Series. 2006;321:267-281.

12. Ayodyoa. Fishing methods. College improvement/development project, Bogor agricultural institute. Bogor. 1975.

13. Pratama MAD, Hapsari TD, Triarso I. Factors affecting the production of purse seine unit in fishing base muncar fishing port banyuwangi, East Java. Saintek Perikanan: Indonesian Journal of Fisheries Science and Technology. 2016;11(2).

14. Aji IN, Wibowo BA, Asriyanto A. Analysis of production factors of cantrang fishing gear catch at fish feather landing base in Tuban Regency. Journal of Fisheries Resources Utilization Management and Technology. 2013.

15. Rachman S, Purwanti P, Primyastanto M. Analysis of production factors and business feasibility of payang fishing equipment in Gili Ketapang, Probolinggo Regency, East Java. Jurnal ECSOFiM. 2013;1(1):70-81.
16. Hufiadi H, Mahiswara M. Arad (Mini Bottom Trawl) Nets Selectivity Equipped with Jteds Against Beloso Fish (Saurida sp.). BAWAL Widya Capture Fisheries Research. 2009.

17. Anggreini AP, Raka Wiadnya DG. Gillnet millenium fishing gear selectivity test on Rastelliger brachysoma. JFMR-Journal of Fisheries and Marine Research. 2017;1(1):24-30.

18. Fish H, Chen Shenyi. Water resources management. World Water '86. Proc. ICE Conference, London; 1987.

19. National Research Council. Effects of trawling and dredging on seafloor habitat. Washington DC: The National Academies Press; 2002.

20. Macfadyen G, Huntington T, Cappell R. Abandoned, lost or otherwise discarded fishing gear. FAO fisheries and aquaculture technical paper 523. 2009.

21. Badrudin M, Karyana. Abundance index of demersal fish resource stock in Kalimantan's West Coast waters. Journal of Marine Fisheries Research No. 71 of 1992. Jakarta: BPPL; 1992. 